\begin{tabular}{|l|l|l||}
\hline \multicolumn{2}{|c|}{ PublisherInfo } \\
\hline \hline PublisherName & $:$ & BioMed Central \\
\hline \hline PublisherLocation & $:$ & London \\
\hline \hline PublisherImprintName & $:$ & BioMed Central \\
\hline \hline
\end{tabular}

\title{
Many cloned mice
}

\begin{tabular}{|l|l|l||}
\hline \multicolumn{2}{|c|}{ ArticleInfo } \\
\hline \hline ArticleID & $:$ & 3779 \\
\hline \hline ArticleDOI & $:$ & $10.1186 /$ gb-spotlight-20000925-03 \\
\hline \hline ArticleCitationID & $:$ & spotlight-20000925-03 \\
\hline \hline ArticleSequenceNumber & $:$ & 216 \\
\hline \hline ArticleCategory & $:$ & Research news \\
\hline ArticleFirstPage & $:$ & 1 \\
\hline \hline ArticleLastPage & $:$ & 2 \\
\hline \hline & $:$ & RegistrationDate : 2000-09-25 \\
ArticleHistory & $:$ & OnlineDate $: 2000-09-25$ \\
\hline \hline ArticleCopyright & $:$ & BioMed Central Ltd2000 \\
\hline \hline ArticleGrants & $:$ & \\
\hline \hline ArticleContext & $:$ & 130591111 \\
\hline \hline
\end{tabular}




\section{William Wells}

Email: wells@biotext.com

The nuclei used in cloning may not go through all the changes that normally reset a gamete nucleus, and thus there have been fears of premature aging and shortened telomeres (an age-related phenomenon) in cloned animals. Indeed, shortened telomeres have been seen in cloned sheep, although the reverse is true for cloned cows. Now in the 21 September Nature Wakayama et al. report that mice reiteratively cloned for up to six generations show no signs of premature aging or shortening of telomeres (Nature 2000, 407:318-319). The success rate of cloning does drop in later generations, however, meaning that the team had to inject a total of 3920 enucleated oocytes over the multiple generations to come up with a single sixth generation clone. After all that effort and technology a more basic biology took over, as the lone survivor was cannibalized by its foster mother.

\section{References}

1. Analysis of telomere lengths in cloned sheep.

2. Extension of cell life-span and telomere length in animals cloned from senescent somatic cells.

3. Nature, [http://www.nature.com/nature/] 